KATARZYNA UZAR-SZCZEŚNIAK

Forum Pedagogiczne

Instytut Pedagogiki

$2015 / 2$

Katolicki Uniwersytet Lubelski Jana Pawła II

Lublin

\title{
PERSONALISTYCZNA PERSPEKTYWA STAROŚCI I JEJ IMPLIKACJE DLA PEDAGOGII OSOBY
}

Streszczenie: Starość jest jednym ze współczesnych wyzwań pedagogicznych. Rozwijane są coraz szerzej teoretyczne i praktyczne aspekty geragogiki. Personalistyczna koncepcja człowieka stanowić może dla nich odpowiednią podstawę. Wynikająca z niej realistyczna i pozytywna, ugruntowana metafizycznie i etycznie wizja starości jako czasu najbliższego osiągnięcia pełni osobowego rozwoju uzasadnia podejmowanie działań wychowawczych dotyczących tego etapu życia. Przyjmować mogą one postać wychowania do starości, w starości i przez starość oraz obejmować osoby i społeczeństwa. Potencjalny projekt integralnego, permanentnego wychowania w perspektywie starości napotyka jednak obiektywne przeszkody uwarunkowane specyfiką funkcjonowania osób starszych i środowisk, w których żyją. Przeżywanie starości na miarę posiadanej godności osobowej, będące celem personalistycznej pedagogii starości zaprezentowanej w artykule, stanowi możliwe, lecz wymagające wyzwanie dla seniorów i starzejących się społeczeństw.

Słowa kluczowe: starość, personalistyczna koncepcja starości, wychowanie w perspektywie starości, pedagogia osoby

Już od kilku dekad starość stanowi nośny temat życia społecznego i badań naukowych w Polsce. Jest przedmiotem debat m.in. nad systemem wsparcia i opieki, zastępowaniem pokoleń na rynku pracy, tworzeniem programów aktywizacji oraz adaptacji seniorów do zmieniających się warunków socjokulturowych i ekonomicznych. Wzrasta liczba publikacji naukowych o tematyce gerontologicznej, a także inicjatyw społecznych, lokalnych i krajowych skierowanych do osób starszych i ich środowisk. Wprowadzona została również m.in. „Długofalowa strategia polityki senioralnej”, dająca podstawy prawne i wsparcie finansowe dla tego rodzaju działalności. Fakty te wpisują się w nurt pozytywnego zainteresowania starością, ukierunkowanego na poprawę sytuacji seniorów. Temat starości stopniowo przenika do świadomości społecznej i ma coraz pozytywniejszy wydźwięk. Zawsze oczywiście pozostaje pytanie, czy istnieje przełożenie między postulatami i faktycznymi działaniami, akcjami społecznymi i codziennym życiem „statystycznego” 
seniora w Polsce, które do najłatwiejszych nie należy. Starość wciąż stanowi - coraz częściej podejmowane, ale jednak - wyzwanie.

Tak jest również w dziedzinie edukacji i wychowania. Obszar teorii i praktyki pedagogicznej w szerszym zakresie obejmuje całe życie człowieka, w tym starość. Oczywiście postulaty uczenia się przez całe życie mają swoją długą tradycję, niemniej jednak geragogika ${ }^{1}$ jako dyscyplina naukowa zajmująca się edukacją i wychowaniem ludzi starszych jest „wynalazkiem” XX wieku, a jej postulaty zaczynają dopiero sukcesywnie przenikać do praktyki pedagogicznej. Tak jak w innych dziedzinach pedagogiki, również w geragogice zachodzi potrzeba systematyzacji teoretycznych podstaw, warunkujących niepozbawioną refleksji praktykę w zróżnicowanych obszarach - od seniorskich form wsparcia, opieki i edukacji aż po samowychowanie w starości. Tego rodzaju podstaw dostarczyć może filozofia personalistyczna, wnosząca odmienne spojrzenie na samą starość oraz proces wychowania w perspektywie starości i czyniąca go sensownym i możliwym. Pedagogia starości napotyka współcześnie wiele wyzwań o charakterze podmiotowym i przedmiotowym. Ich charakterystyka stanie się również przedmiotem tego artykułu. Całość rozważań służyć ma prezentacji personalistycznego ujęcia starości i wynikających z niego tez, istotnych z punktu trwającego całe życie wychowania człowieka $^{2}$. Metodologiczną podstawę dla nich stanowi metoda hermeneutyczna, której przedmiotem stały się teksty filozoficzne i pedagogiczne dotyczące starości, jak również doświadczenie pracy edukacyjnej i terapeutycznej w instytucjonalnych i środowiskowych formach wsparcia dla seniorów.

\section{Starość i rozwój człowieka starszego w ujęciu personalistycznym}

Dla zakreślenia obszaru analiz istotne jest zdefiniowanie podstawowych terminów wpisujących się w zakres tematyczny niniejszego tekstu. Pierwszym z nich jest s t a r o ś ć , w gerontologii społecznej określana jako „nieunikniony efekt (końcowy etap) starzenia się, w którym procesy biologiczne, psychiczne i społeczne zaczynają oddziaływać na siebie synergetycznie, prowadząc do naruszenia równowagi biologicznej i psychicznej bez możliwości przeciwdziałania temu [...]. Za początek starości przyjmuje się umownie 60. lub 65. rok życia, a nieuchronnym końcem starości jest śmierć” (Zych 2007, s. 163). W aspekcie statycznym ujmowana jest jako okres życia następujący po wieku dojrzałym, natomiast w dynamicznym jako

1 Termin stosowany w tekście zamiennie z określeniami „pedagogia starości” i „wychowanie w perspektywie starości”, między którymi istnieją różnice znaczeniowe, głównie w aspekcie odniesienia do teorii (geragogika) bądź praktyki wychowania (pedagogia starości, wychowanie w perspektywie starości).

2 Tematyka ta została w sposób systematyczny opracowana w publikacji Wychowanie w perspektywie starości. Personalistyczne podstawy geragogiki (Uzar 2011). Treść niniejszego artykułu stanowi zaktualizowany skrót jej najważniejszych tez, uzupełniony o problematykę współczesnych wyzwań geragogiki. 
proces starzenia się. Podkreślić należy, że starość jest najbardziej zróżnicowaną ze wszystkich faz życia (Czerniawska 20oob). Zróżnicowanie to dotyczy specyfiki funkcjonowania osób starszych w danym przedziale wiekowym, obszarów życia, w których proces starzenia się przejawia (starość społeczna, ekonomiczna itd.), wreszcie sposobów jego przeżywania, warunkowanych m.in. indywidualną historią życia, cechami osobowościowymi, czynnikami sytuacyjnymi. Jest to istotny fakt, znajdujący swoje odzwierciedlenie w personalistycznej koncepcji starości.

Tak zdefiniowana starość rozpatrywana będzie z punktu widzenia filozofii personalistycznej. Perspektywę interpretacyjną artykułu stanowi p e r s o n a li z m et y c z n y, będący syntezą personalizmu w odmianie metafizycznej i liberalistycznej, słownikowo określany jako „teoria opierająca się na moralnym znaczeniu osoby" (Chudy 1998, s. 76). Łączy ona w sobie obiektywny, ontyczny wymiar człowieka-osoby z subiektywnym aspektem przeżywania siebie jako osoby. Człowiek nie tylko jest osobą, ale doświadcza siebie i działa jako osoba. Centralną wartością, będącą zarazem kryterium moralnym ludzkich czynów decydujących o osobowym spełnianiu się, jest godność osobowa. Implikuje ona również postawę miłości jako najpełniejszą formę relacji międzyosobowych afirmujących godność ich uczestników. Do przedstawicieli personalizmu w omawianym nurcie należą: Karol Wojtyła, Tadeusz Styczeń, Wojciech Chudy. Spróbujmy zatem wskazać, co wnosi ujęcie personalistyczne do rozumienia samej starości, a w dalszej kolejności wychowania dotyczącego tego etapu życia.

Analizując byt człowieka od strony metafizycznej, wyróżnić w nim można cechy istotowe i przypadłościowe. C e chy is t o to w e, na które składają się indywidualność, substancjalność, racjonalność, wynikające m.in. z boecjańskiej definicji osoby jako „jednostkowej substancji natury rozumnej” (Krąpiec 1991, s. 404), oraz oparte na nich zdolności do rozumnego, wolnego opowiadania się za prawdą, transcendencji, miłości, stanowią niezmienny, ontyczny szkielet bytu osobowego. W tej płaszczyźnie sytuuje się również godność osobowa człowieka, stanowiąca o istocie jego życia i działania. Wskazane cechy tworzą constans w toku życia, świadczą o „odporności i ontycznej doskonałości bytu człowieka”, niezależnej, a nawet utrwalającej się z biegiem lat, bowiem „trwanie istnienia to bogacenie bytu, potęgowanie jego wartości” (Pastuszka 1999). Jest to również wymiar, który decyduje o poczuciu własnej tożsamości, od strony przeżyciowej dający obraz bycia sobą niezależnie od wieku. Jak stwierdza Jan Szczepański: „moja identyczność jest zagwarantowana niezmiennością świata wewnętrznego, w którym nie ma starości, a którego projekcje w świat zewnętrzny orzekają o mojej naturze, o tym, czym jestem naprawdę, mimo złośliwości czasu niszczącego mój organizm i psychikę" (Szczepański 1988, s. 287). Istotowe cechy osoby stanowią również podstawę optymizmu metafizycznego, nadającego sens ludzkiej egzystencji mimo doświadczanych w toku życia zmian i ograniczeń.

Podlegają im ciało i psychika, będące podłożem c e ch p r z y p a d ło śc i o w y c h, które w starości uwidaczniają się w sposób szczególny. W sferze fizycznej 
zaobserwować można stopniowy, przebiegający z różnym nasileniem spadek sprawności, przejawiający się m.in. w poczuciu zmęczenia, trudnościach w poruszaniu się, częstszych chorobach, osłabieniu funkcjonowania zmysłów, a tym samym w utrudnieniach komunikacji z otoczeniem. Doświadczenie starości trudnej, zniedołężniałej staje się udziałem wielu osób, choć nie dotyczy wszystkich. Psychika człowieka starszego cechuje się specyficzną dialektyką intelektu i emocji, stanowiąc swoisty pomost pomiędzy sferą duchową i cielesną. Z jednej strony, uwidacznia się tu rola doświadczenia i mądrości życiowej, tonujących uczuciowy stosunek do rzeczywistości, z drugiej zaś - procesy myślenia łączą się z pewnym wysiłkiem i nie są już tak płynne jak we wcześniejszych okresach życia (Uzar 2011).

Fakt ten związany jest również z aktami woli, podlegającymi różnego rodzaju ograniczeniom, w szczególności ze strony starzejącego się ciała. Już u początku procesu decyzyjnego osoba starsza napotkać może utrudnienia w odbiorze informacji z otoczenia na skutek np. osłabionego wzroku lub słuchu. Również efekt finalny podjętej decyzji może nie zostać zrealizowany na skutek ograniczonej sprawności. Człowiek starszy bywa powstrzymywany w sferze dokonań zarówno na poziomie poznania, wolnego decydowania, jak i działania ${ }^{3}$.

Józef Pastuszka opisuje ten fakt w następujący sposób: „u ludzi starych [...] inteligencja, nieraz wybitna, nie idzie w parze $z$ wolą. Ta bowiem zazwyczaj wiąże się z czynem, z działaniem, z wysiłkiem, a tego ludziom starym brakuje. Starość najpierw atakuje siły fizyczne, a te muszą w jakiś sposób towarzyszyć woli. Ich brak albo obawa, że nie wystarczą, paraliżuje aktywność woli” (Pastuszka 1999, s. 37). Tak więc ciało może znacznie utrudniać autonomiczne działanie człowieka starszego, aczkolwiek go nie uniemożliwia. Bezpośrednie doświadczenie starości jest osadzone szczególnie w wymiarze psychofizycznym, którego braki uwidaczniać mogą jednak głębszy wymiar ludzkiej egzystencji - jak pisze Józefa Hennelowa: „Myślę, że człowiek, który chodzi z trudem, który przy każdym wsiadaniu na przystanku staje przed problemem, czy mu się uda [...], człowiek, który potyka się o własną pamięć z coraz większymi dziurami, [...] którego [...] osacza coraz mniej pokonywalny bałagan w domu albo coraz bardziej skomplikowane zadanie utrzymania higieny osobistej - że ten człowiek cały jest duchem i ciałem o wiele bardziej niż człowiek w pełni sił” (Owsiany 2003, s. 8). Ograniczenia starości są jednocześnie wyzwaniami w perspektywie osobowego rozwoju człowieka.

Odwołując się do arystotelesowskiej teorii złożenia bytowego, wskazującej na dwa podstawowe wymiary każdego bytu: akt - istnienie oraz możność - istotę, wysunąć można tezę o osobowym stawaniu się człowieka. Wartość osoby, stanowiąca o istocie człowieczeństwa, jest równocześnie zadana do realizacji w toku całego życia, człowiek jest, a zarazem staje się osobą. Otwiera się tu przestrzeń osobowego

${ }^{3}$ W szczególnych przypadkach, związanych np. z chorobą Alzheimera, zdolności te zostają ograniczone lub całkowicie zniesione. 
rozwoju, który dokonuje się w działaniu i osadzony jest w czasie ${ }^{4}$. Od strony moralnej rozwój ten wiąże się ze skutkami dokonywanych czynów, w szczególności nieprzechodnimi, pozostawiającymi w podmiocie działania „osad” dobra lub zła moralnego - afirmującymi bądź deprecjonującymi godność osobową. Od strony metafizycznej rozwój polega na stawaniu się coraz bardziej aktem w stosunku do posiadanych możności. Starość, z racji przeżytych lat i nabytych doświadczeń szans na doskonalenie rozumnego poznania i działania, jest okresem najbliższym osiągnięciu optimum potentiae - szczytu ludzkiej potencjalności działania (Krąpiec 2000, s. 109), a tym samym pełni osobowego rozwoju w wymiarze doczesnym. Tezę tę wydaje się potwierdzać zjawisko tzw. a n t y n o m i i ro z w o j ow e j, doświadczanej w starości. Fizycznej inwolucji towarzyszyć może wzrost znaczenia i rozwój wymiaru duchowego, jak stwierdza jeden z seniorów: „odnoszę wrażenie, że wraz z ubytkiem sił fizycznych staję się jakby bogatszy duchowo. To mi tłumaczy sens długiego życia” (cyt. za: Pawlukiewicz 1998, s. 91). Podstawą rozwoju duchowego w okresie starości jest wymiar ontyczny człowieka, niezmieniający się z biegiem lat i towarzyszących im przemian.

Takie ujęcie starości wnosi odmienne spojrzenie na sytuacje choroby i śmierci, nieodłącznie wpisane w ten etap życia. Nie negując ładunku egzystencjalnego, trudu i cierpienia z nimi związanych, ukazuje ich „osobotwórczy” charakter. Odpowiednio przeżyte odsłaniają bowiem istotę człowieczeństwa - seniorom i osobom z ich otoczenia. Ś m i e r ć zyskuje nowy, różny od biologicznego i deterministycznego charakter - jest najwy ż z y m c zynem człowieka w $\dot{z}$ yciu (Spaemann 2001), który może zostać świadomie podjęty. Wsparciem w tym może być chrześcijańska perspektywa życia wiecznego, związana z podejściem personalistycznym. Takie spojrzenie na chorobę i śmierć wyklucza sytuacje eutanazji i uporczywej terapii, odmawiania statusu osoby ludziom chorym, pozbawionym świadomości, wskazując na godność osobową przynależną każdemu człowiekowi od poczęcia do naturalnej śmierci.

Podsumowując analizę personalistycznego ujęcia starości, sformułujmy definicję obejmującą najistotniejsze tezy tej koncepcji. Tak więc s t a rość w ujęc i u p e r s o n a l i s t y c z n y m to końcowy etap w naturalnym biegu egzystencji człowieka, potencjalnie najbliższy jego osobowego urzeczywistnienia się, którego ostatnim momentem w wymiarze doczesnym jest śmierć pojęta czynnie, rozumiana jako najwyższy ludzki akt. Szczególną wartością, a zarazem zadaniem do realizacji w okresie starości (w wymiarze indywidualnym i społecznym) jest afirmacja osobowej godności człowieka (Uzar 2011, s. 133). Ujęcie to wnosi pozytywną wizję tego okresu życia, wskazując na jego potencjał w wymiarze metafizycznym, moralnym i egzystencjalnym. Starość jest ważnym i dynamicznym etapem trwającego całe

4 Szczególną rolę odgrywa tu wymiar czasu kairos, będący „czasem wieczności”, dotyczącym treści jakie wypełniają życie człowieka, w odróżnieniu od czasu chronos, mówiącego o chronologicznym upływie dni, miesięcy, lat (por. Czerniawska 20ooa). 
życie procesu rozwoju osobowego, a jej potencjał implikuje sensowność i potrzebę działań (samo)wychowawczych podejmowanych w różnych okresach życiowych przez zróżnicowane podmioty.

\section{Personalistyczne podstawy geragogiki}

Spróbujmy zdefiniować wychowanie w perspektywie starości w oparciu o tezy filozofii personalistycznej. Pomocna w tym będzie definicja wychowania Janusza Tarnowskiego, osadzona w nurcie pedagogiki personalno-egzystencjalnej (Tarnowski 1992, s. 121), uwzględniająca specyfikę starości. W y c ho w a n i e w perspektywie sta r ości określić możemy zatem jako całokształt sposobów i procesów, umożliwiających człowiekowi-osobie żyjącemu w egzystencjalnej perspektywie starości, zwłaszcza przez samowychowanie i uczestnictwo w międzyosobowych relacjach, afirmację i urzeczywistnienie godności osobowej, przynależnej mu od momentu poczęcia do naturalnej śmierci (Uzar 2011, s. 145). Obejmuje ono, w zależności od grupy odbiorców, trzy główne obszary: wychowanie do starości, skierowane do tych, którzy nie znajdują się jeszcze na tym etapie życia, lecz doświadczają go w sposób pośredni (od dzieciństwa po dorosłość), wychowanie w starości, dotyczące bezpośrednio osób starszych, oraz wychowanie przez starość, dokonujące się za pośrednictwem seniorów, w środowiskach, w których żyją. Obszary te nie są rozłączne, obejmują wszystkie okresy życia człowieka, w sposób integralny we wszystkich sferach jego funkcjonowania.

Zagadnienia te są przedmiotem naukowej refleksji podejmowanej na gruncie geragogiki - stosunkowo młodej dyscypliny naukowej ${ }^{5}$, w Polsce zapoczątkowanej przez Aleksandra Kamińskiego (Kamiński 1986), obecnie dynamicznie się rozwijającej. Szczegółowa charakterystyka wychowania w perspektywie starości wykracza poza ramy artykułu. Ograniczę się więc do przedstawienia głównych tez dotyczących celów, relacji wychowawczej, perspektywy czasowej, stosowanych metod i wymiaru środowiskowego. Tworzą one proponowane teoretyczne podstawy geragogiki personalistycznej.

Głównym c e l e m wychowania w perspektywie starości jest afirmacja i urzeczywistnienie godności człowieka starszego. To szeroko sformułowane zadanie przekłada się na: konieczność odkrycia sensu i znaczenia starości w życiu człowieka, budowanie pozytywnych postaw wobec seniorów, a także stworzenie warunków umożliwiających godne przeżywanie tego okresu życia. Cele te realizowane są w płaszczyznach: podmiotowej - indywidualnej i przedmiotowej - społecznej, którym odpowiadają określone c e le s z c z e g ółowe.

5 Termin wprowadzony przez niemieckich uczonych Ferdynanda Adalberta Kehrera (1952) i Hansa Mieskesa (1956) i oznaczający edukację i wychowanie osób starzejących się i starych (zob. Dubas 2005; Szarota 2004). 
Pierwsza płaszczyzna obejmuje przede wszystkim osoby starsze w ich wysiłku samowychowawczym skierowanym „ku sobie”, „ku światu” i „ku transcendencji” (Uzar 2011). Skierowanie ku sobie oznacza trud poznania, zrozumienia i przyjęcia prawdy o starości. Cel ten stoi w opozycji do lansowanych współcześnie wzorców ageless body - niestarzejącego się ciała (Katz, Marshall 2003) czy old boys/ old girls - niestarzejących się seniorów, za wszelką cenę usiłujących zachować młodzieńczy wygląd i sposób zachowania. Akceptacja ograniczeń starości jest zadaniem trudnym. Jest jednak warunkiem rozwoju osobowego, który w tym okresie życia „paradoksalnie [...] polega często na traceniu, na wypuszczaniu z rąk, na zgodzie na zamykanie różnych drzwi, na przyjęciu zacieśniających się granic" (Myszka-Wieczerzak, Sękalska 2009, s. 317). Postawa ta stwarza pewną przestrzeń wewnętrznej wolności, pozwalając na adaptację, ale również na kształtowanie woli i dokonywanie ostatnich poprawek w projekcie życia.

Rozwój człowieka starszego dokonuje się również w interakcjach z otoczeniem. Dlatego też, zgodnie z przesłaniem mądrości o skorupce, która trąci tym, czym za młodu nasiąknie, ważne jest kształtowanie wzorców aktywnego, otwartego na kontakty z innymi sposobu spędzania czasu już we wcześniejszych okresach życia (Kamiński 1986). W starości jest to szczególne wyzwanie dla mężczyzn, którzy z racji „zadaniowej” orientacji życiowej dotkliwiej doświadczają konsekwencji przejścia na emeryturę (Kluczyńska 2010). Bliskie relacje odgrywają kluczową rolę w pozytywnym przeżywaniu starości. Stwarzają przestrzeń wymiany, dzielenia się doświadczeniami, wzajemnej pomocy, zwłaszcza w sytuacji ograniczonej sprawności. Okazją do ich budowania mogą być zróżnicowane działania o charakterze społecznym, kulturalnym i edukacyjnym.

Przekraczanie siebie w kierunku drugiego człowieka koresponduje z odniesieniem doświadczeń starości do wartości absolutnych. Jest to praca nad sobą w perspektywie „ku transcendencji”. Ważnym jej wymiarem jest dokonywanie bilansu życia, oceny dotychczasowych doświadczeń również w aspekcie moralnym. Jej rezultat przyczyniać się może do akceptacji i poczucia zadowolenia z całokształtu życia bądź - wręcz przeciwnie - stać się źródłem żalu, poczucia niespełnienia i rozgoryczenia. Możliwe jest również odkrycie sensu doświadczeń negatywnych w łączności z wartościami stricte duchowymi, w szczególności chrześcijańskimi. Cierpienie, lęk, samotność towarzyszące starości mogą zostać odniesione do wartości miłości i miłosierdzia, zbawienia i perspektywy zmartwychwstania (Ślipko 1999), a także do postawy ponoszenia ofiary dla drugiego człowieka. Przekraczanie siebie i własnej starości dokonuje się na drodze refleksji, świadomego uczestnictwa w codzienności, odsłaniającego znaczenie poszczególnych wydarzeń w osobowym rozwoju człowieka.

Przedmiotowa perspektywa celów pedagogii starości obejmuje w głównej mierze budowanie społecznej świadomości dotyczącej tego etapu życia. Znajomość specyfiki i potrzeb starości pozwala członkom różnych grup społecznych na głębsze zrozumienie, akceptację i wsparcie seniorów, a także przygotowanie się do własnego 
starzenia się. Służy temu zapewnienie odpowiedniego zabezpieczenia materialnego, zdrowotnego, opiekuńczego, ale także, a może nawet przede wszystkim, tworzenie właściwych, ugruntowanych aksjologicznie, postaw społecznych. Trafnie określił to Jan Paweł II, mówiąc o „konieczności odzyskania człowieka starszego, jego doświadczeń i obecności” (Jan Paweł II 1993, s. 785) w życiu społecznym i przywrócenia w nim równowagi międzypokoleniowej. Będzie się to wyrażać w działaniach ukierunkowanych na czynne uczestnictwo seniorów w aktywności społecznej rodzinnej, zawodowej, kulturalnej, edukacyjnej. Ważne jest również stwarzanie okazji do spotkania pokoleń, wzajemnego uczenia się, przede wszystkim postawy miłości „stanowiącej wyraz szczególnego daru i wymiany - wstępującego i zstępującego życia osobowego" (Chudy 1999, s. 34). Wymienione wyżej zadania winny być realizowane przez różne podmioty życia społecznego.

Relacja wychowawcza w pedagogii starości wykazuje swoistą dynamikę i zależność od etapu życia oraz indywidualnych czynników rozwojowych. Niewątpliwie kluczem jest tu proces samowychowania. Potencjalnie liczba nabytych doświadczeń, mądrość życiowa, sprawność w decydowaniu predysponują osoby starsze do pracy nad sobą, w której wychowawca zewnętrzny pełnić może jedynie rolę wspierającego towarzysza. Samowychowanie wymaga samoświadomości i wysiłku woli, ukształtowanych we wcześniejszych etapach życia. Ważne jest zatem wdrażanie młodego pokolenia w proces pracy nad sobą, zwłaszcza u progu dorosłości. Syntetyzując ujęcie relacji wychowawczej w pedagogii starości, można stwierdzić, że udział samowychowawczej aktywności wychowanka jest wprost proporcjonalny do jego wieku, etapu rozwojowego oraz indywidualnych uwarunkowań, odwrotnie zaś do działań wychowawców zewnętrznych (Uzar 2011). Pedagogia starości bywa określana jako „wychowanie bez wychowawcy” (Machowicz 2003), w którym osoba starsza staje się swoim nauczycielem i przewodnikiem.

Całość działań wychowawczych i samowychowawczych osadzona jest w perspektywie czasowej, która w przypadku starości ma kierunek odwrotny do pedagogii dzieci i młodzieży. Chodzi o wyakcentowanie przeszłości i teraźniejszości, o swoistego rodzaju meliorację i redefinicję przeszłych wydarzeń życiowych, by otworzyć się na czas teraźniejszy (Homplewicz 2003), odkryć wartość aktualnych doświadczeń i dobrze je przeżyć (carpe diem), a w dalszej kolejności zaakceptować coraz bliższy koniec życia (memento mori) (Chudy 2007). Zofia Starowieyska-Morstinowa tak pisze o tym doświadczeniu: „Cieszę się dniem dzisiejszym. Wiem, że ma w sobie skarby nieprzebrane. A może tak chętnie zatrzymuję na nim oczy, bo słowo «jutro» z każdym dniem staje się groźniejsze” (Starowieyska-Morstinowa 1982, s. 206). Integracja wszystkich perspektyw czasowych sprzyja rozwojowi osobowemu, który jest niełatwym i coraz bardziej „przynaglającym” zadaniem w starości.

Metodyka pedagogii starości stanowi coraz lepiej opracowaną dziedzinę refleksji pedagogicznej. Wspomnieć tutaj trzeba o konieczności zróżnicowania działań pedagogicznych w zależności od sfer funkcjonowania człowieka starszego. Inną specyfikę będą posiadały działania ukierunkowane na rozwój duchowy i osobowościowy 
osób starszych, wśród których można wymienić m.in. kształtowanie kompetencji biograficznej - sztuki świadomego i odpowiedzialnego kierowania własnym rozwojem (Pietrasiński 1990), techniki reminiscencyjne mające na celu „odpominanie” i wartościowanie wydarzeń z przeszłości (Steuden 2011), pozytywne przeżywanie samotności jako sposób budowania własnej tożsamości i odkrywania sensu życia czy życie religijne, szczególnie ważne w wieku senioralnym, a inną działania skierowane na interakcje $z$ otoczeniem, takie jak np. podejmowanie zróżnicowanych form aktywności społecznej, kulturalnej czy edukacyjnej. Kluczem jest adekwatny do możliwości i preferencji starszych osób dobór form, metod i technik. Wartość koncepcji personalistycznej polega na pozytywnym, ale i realistycznym podejściu do zaangażowania seniorów, opartym na „prawdzie o wartości i spełnieniu osobowym jako niezależnych od «zewnętrznych aktywności» czy sprawnego intelektu" (Wałejko 2010).

Scharakteryzowane powyżej teoretyczne podstawy pedagogii starości realizowane są w zróżnicowanych kontekstach sytuacyjnych i środowiskowych. Bezpośredni kontakt z osobami starszymi daje możliwość weryfikacji proponowanych tez oraz wskazania wynikających z praktyki wyzwań do rozwiązania na gruncie refleksji gerontologicznej.

\section{Współczesne wyzwania pedagogii starości}

Optymistyczne przesłanie filozofii personalistycznej o możliwości, a zarazem potrzebie, rozwoju i wychowania człowieka starszego posiada również cechę realizmu, bo bazuje na prawdzie o starości, koniecznej do uwzględnienia w działaniach pedagogicznych. Realizm ten dotyczy zarówno cech samej starości, jak też kontekstów środowiskowych, w których jest przeżywana. W obu tych wymiarach obecne są ograniczenia warunkujące wychowanie i samowychowanie.

Rozwój w starości określany bywa dziełem „arystokratów ducha” (Straś-Romanowska 2010). Jest to zadanie trudne i realizowane przez nielicznych, co jednak nie znaczy, że niemożliwe. Na trud składają się przede wszystkim wspomniane ograniczenia w podejmowaniu wolnych decyzji. Dzieje się tak z kilku powodów. Po pierwsze, jest to sprawność nabywana w toku całego życia, której efekty zależą od umiejętności rozpoznawania dobra i realizowania go w działaniu, kształtowanej od najmłodszych lat. Nie wszyscy, z różnych przyczyn, umiejętność tę posiadają. Fakt ten dotyczy również relacyjnego wymiaru pedagogii starości. Pomyślne przeżywanie starości związane jest z obecnością drugiego człowieka, co wymaga otwartości i umiejętności budowania relacji. I choć ukierunkowanie na autorefleksję, koncentracja na własnej kondycji egzystencjalnej, nie jest w starości niczym złym (Czerniawska 2ooob), to jednak „łatwiej godzą się [z nią - K.U.-S.] ci, którzy od młodości dostrzegali bliźnich" (Leclercq 1978, s. 49). Rozwój osobowy przez pracę nad sobą i w relacjach z innymi jest owocem wcześniejszych doświadczeń i działań, a w starości stanowić może jeszcze większe wyzwanie. 
Wymienić trzeba również ograniczenia psychofizyczne, a także specyficzny kontekst egzystencjalny starości. Utrudnienia w pracy nad sobą i adaptacji do starości stanowić mogą: materialistyczne nastawienie (Starowieyska-Morstinowa 1982), brak otwartości na zmiany (Pastuszka 1999), konserwatyzm, postawa autorytarna i roszczeniowa, kurczowe trzymanie się przeszłości i jej idealizacja (Ringel 1976), ogólne zmęczenie, niechęć do działania, określane przez starożytnych jako taedium vitae - znużenie życiem (Leclercq 1978, s. 107). Cechy te są w pewien sposób uzasadnione. Człowiek starszy ma prawo odczuwać ciężar lat i związanych z nimi doświadczeń - troska o wymiar materialny może być wyrazem „instynktu samozachowawczego, woli zachowania życia” (Pastuszka 1999), w starości w pewnym stopniu zagrożonego; potrzeba stabilizacji i przewidywalności życia, skądinąd niezależna od wieku, zostaje zachwiana przez gorsze samopoczucie, ograniczające możliwości i plany; wkład całożyciowego zaangażowania w życie społeczne domaga się gratyfikacji, a na pewno szacunku; postawa konserwatywna ma także zalety może chronić przed relatywizmem, odsłaniając wartości niezmienne, stanowiące o istocie ludzkiego życia; wracanie do przeszłości sprzyja nabieraniu dystansu, nabywaniu wewnętrznej wolności w przeżywaniu okresu starości. Trzeba zatem do tych prawd o starości podejść w myśl zasady złotego środka: widząc, kiedy nadmiar lub niedomiar może rozwojowi osobowemu szkodzić. Trzeba również jasno stwierdzić, że rozwój w starości jest walką i trudem, że „trzeba niejedno wycierpieć i niejedno przecierpieć, aby naprawdę zaakceptować swą starość” (Ringel 1976, s. 26).

Kluczem jest odniesienie do wymiaru duchowego - odkrycie wartości innych niż doczesne, nadających sens zmaganiom starości. Jak pisze Josefine Gangl: „równolegle z utratą sił fizycznych winien iść rozwój wartości w dziedzinie ducha, uzależniony [...] od wewnętrznego zdyscyplinowania. Wobec coraz większej potrzeby spokoju i odpoczynku należałoby koncentrować się na tym, co istotne w życiu, odsuwając to, co niepotrzebne: pozbywać się balastu, aby zdobywać coraz większą wewnętrzną wolność” (Gangl 1976, s. 163). Sprzyjają temu odpowiednie okoliczności: większa ilość wolnego czasu, wyłączenie z intensywnej aktywności społecznej, refleksyjność, sytuacje graniczne motywujące do pytania o najistotniejsze sprawy życiowe. W ten sposób dokonywać się może proces „wzrastania w starości” (King 2004, s. 141) w oparciu o duchowe zasoby i wartości.

Płaszczyzna ta jest także istotna w działaniach środowiskowych dotyczących osób starszych. Zmierzają one do stworzenia godnych warunków starzenia się w wymiarach: materialnym, zdrowotnym, społecznym, kulturalnym. Ważne jednak, aby nie ograniczały się tylko do zewnętrznego aspektu starości. Jest ona bowiem „problemem zasadniczo ludzkim” (Jan Paweł II 1993, s. 785), którego rozwiązanie możliwe jest tylko przy uwzględnieniu prawdy o osobowej godności człowieka. Warto zatem przyjrzeć się przykładom wyzwań stojących przed wybranymi środowiskami, próbującymi współcześnie odpowiedzieć na kwestię starości. 
Rodzina jest podstawową komórką życia społecznego i powinna nią pozostać aż do ostatnich dni życia jej członków. Oczywiście nie zawsze jest to możliwe, dzieje się tak z różnych powodów, m.in. tendencji demograficznych i społeczno-kulturowych sprawiających, że rodzina wielopokoleniowa jest dziś rzadkością. Niemniej jednak wciąż pozostaje ona głównym ogniwem w systemie wsparcia i opieki dla osób starszych. Pełnienie tej funkcji nie jest łatwe, wymaga dużego zaangażowania jej członków i domaga się odpowiedniego wsparcia ze strony podmiotów zewnętrznych. Jak wiadomo, sytuacja polskich rodzin w tym zakresie nie jest zadowalająca. Traktowane są one jako „niewidoczne” podmioty wsparcia, borykające się z wieloma trudnościami natury organizacyjnej, ekonomicznej i emocjonalnej (Racław 2011). Wyzwaniem jest również budowanie pozytywnych relacji między młodszym i starszym pokoleniem w rodzinie. Często starsi tracą w niej rolę autorytetu, a młodzi nie czują się rozumiani. Zachodzi potrzeba dialogu, akceptacji i korzystania $z$ atutów obu pokoleń. Trafnie prawdę tę obrazuje cnota pouczalności - łac. docilitas, przez Jacka Woronieckiego określana jako gotowość do przyjęcia czyjejś rady, zaufanie doświadczeniu drugiej osoby, sprzyjające nabywaniu nowej wiedzy praktycznej i teoretycznej (Woroniecki 1986, s. 35). Cnota ta ma charakter dwukierunkowy - służy młodym, ale i starszym, jest bowiem pochodną roztropności, w której człowiek doskonali się przez całe życie (Tomasz z Akwinu 1964). To potrzeba szacunku dla seniorów, a także ich otwartości wobec młodych. Postawy te sprzyjają uczeniu się międzypokoleniowemu, do którego rodzina stwarza szczególną okazję.

Szereg wyzwań łączy się z dziedziną opieki w sytuacjach nieformalnych i w instytucjach, począwszy od odpowiednich warunków organizacyjnych, finansowych, na samej specyfice relacji opiekuńczych kończąc. Zawsze zakładają one asymetrię ról, stwarzającą ryzyko uprzedmiotowienia, co trafnie opisuje Maura McIntyre: „W chorobie, [...] szczególnie w kontekście demencji, często zapominamy, że relacje są wciąż ulicą dwukierunkową. Łatwo przywiązujemy się do roli i ustanawiamy własne samoobronne dychotomie: pacjenta, ofiary, osoby wymagającej opieki; a z drugiej strony: pomocnika, opiekuna, ratownika. Możemy zapomnieć o obustronności i wzajemności - często zauważamy tylko, co powinno być zrobione, fizyczne objawy choroby, a nie udaje nam się zauważyć osoby, być z nią" (McIntyre 2003, s. 479). Potrzebna jest więc opieka skoncentrowana wokół osoby zamiast „pielęgniarstwa linii produkcyjnej”, zauważenie i afirmacja godności człowieka chorego, starszego w sytuacji, w której często czuje się on zależny od innych. Od osoby starszej zaś wymaga to otwartości i umiejętności przyjmowania pomocy - jak pisze Elżbieta Sujak: „starość i choroba to jest bardzo intensywna szkoła pokory, ponieważ to [...] bycie w prawdzie. I człowiek nagle godzi się na siebie, jakim jest, i rozwija, wychowuje się ku wdzięczności. Wtedy przestaje jej oczekiwać czy domagać się, ale zaczyna ją odczuwać wobec tego, co otrzymuje” (cyt. za: Myszka-Wieczerzak, Sękalska 2009, s. 317). Relacje opiekuńcze stają się dla obu 
stron szczególnym doświadczeniem trudu, własnych ograniczeń, ale również okazją do odkrycia istoty człowieczeństwa, zobowiązującej i motywującej do rozwoju.

Nieco odmienne wyzwania czekają na organizatorów przedsięwzięć edukacyjnych, zarówno stricte seniorskich, jak i tych dotyczących starości, ale skierowanych do innych grup odbiorców. W pierwszym przypadku ważna jest kwestia dostępności i zaangażowania w nie seniorów. Liczba ofert edukacyjnych dla osób starszych w naszym kraju wzrasta i jest to tendencja pozytywna. Niemniej jednak, jak w przypadku UTW, są one elitarne - w zajęciach uczestniczą seniorzy z miast, osoby sprawne, lepiej sytuowane i wykształcone, w większości kobiety (Gołdys i in. 2012). Zachodzi potrzeba stworzenia szerszego wachlarza form edukacyjnych, zróżnicowanego pod względem środowiska zamieszkania, a także możliwości i preferencji uczestników. Ważną kwestię stanowi także włączenie osób starszych w działania na rzecz innych. Traktowanie przez seniorów zajęć edukacyjnych jako formy samorozwoju czy odpoczynku jest uzasadnione. Pozostaje jednak otwarta kwestia działania społecznego: od pomocy osobom potrzebującym (w rodzinie, sąsiedztwie) po organizację przedsięwzięć środowiskowych. Wolontariat osób starszych rozwija się, wciąż jednak stanowi ważny postulat w działaniach edukacyjnych i aktywizacyjnych do nich skierowanych. Duże znaczenie ma również edukacja gerontologiczna: począwszy od kształcenia dzieci (np. obecność tematyki starości w podręcznikach szkolnych), a skończywszy na przygotowaniu profesjonalistów (takich jak pedagog, pracownik socjalny, lekarz, pielęgniarka). Jej istotnym elementem winien być bezpośredni kontakt z osobą starszą, zarówno w roli nauczyciela, przekaziciela doświadczenia, jak i odbiorcy korzystającego ze wsparcia. Odrębnym tematem w przypadku profesjonalizacji opieki jest brak osób chętnych do podejmowania edukacji i pracy w tym obszarze mimo rosnącego zapotrzebowania. Studia gerontologiczne i geriatryczne nie cieszą się popularnością, a oferowane stanowiska pracy są wymagające i mało atrakcyjne finansowo. Również tutaj zachodzi konieczność wypracowania odpowiedniego systemu organizacji i finansowania (Derejczyk in. 2008).

Skutecznym instrumentem zmiany klimatu społecznego wokół starości mogą być media. Także tu powiedzieć można o stopniowym przełamywaniu „seniorskiej ciszy medialnej”. Starość staje się coraz częstszym tematem polskich produkcji filmowych, podejmujących ważne tematy: samotności, choroby, cierpienia, przemian relacji rodzinnych i małżeńskich, odchodzenia i śmierci ${ }^{6}$. Zwiększa się również liczba produktów reklamowanych dla i przez seniorów - stają się wszak coraz większą grupą konsumentów. Ważne jest jednak to, by obraz starości w mediach był rzetelny i pozytywny oraz przekazywany w zrozumiały i atrakcyjny sposób dla wszystkich odbiorców. Aktywna, atrakcyjna fizycznie, wspomagana specyfikami medycznymi i kosmetycznymi starość, pojawiająca się na ekranach telewizorów,

${ }^{6}$ Wymienić tutaj można m.in. produkcje: Pora umierać (2007) i Inny świat (2012) Doroty Kędzierzawskiej, Jeszcze nie wieczór (2009) Jacka Bławuta, Las (2009) Piotra Dumały. 
jest bowiem tylko półprawdą - potencjalnie sprzyjającą zmianie wizerunku społecznego, ale nieuwzględniającą realizmu procesu starzenia się. Istnieje potrzeba wyważenia blasków i cieni starości, przekazywanych w prawdziwy i dostępny sposób. Ważną kwestią jest również cyfrowe wykluczenie osób starszych. Zwiększa się liczba zarówno seniorów korzystających z komputera, internetu, telefonów komórkowych, jak też opcji edukacyjnych służących zwiększeniu ich kompetencji w tym zakresie (Tomczyk 2010). Są to tendencje pozytywne, warto jednak, aby nie były jedynymi obowiązującymi, utrudniając funkcjonowanie osobom preferującym tradycyjne kanały odbioru informacji. Stąd postulat zachowania różnorodności przekazu medialnego oraz niepozbawionej refleksji interpretacji kwestii cyfrowego wykluczenia seniorów, jak bowiem trafnie zauważa Małgorzata Wałejko: „starsi nic nie powinni - to świat powinien nadążyć za nimi; świat winien dostrzec w osobie wartość niezwiązaną bynajmniej ze znajomością Microsoft Office” (Wałejko 2010).

Wskazać można oczywiście wiele innych obszarów rozwoju, a zarazem wyzwań, jakie stoją przed pedagogią starości. Ich realizacja związana jest z koniecznością przyjęcia odpowiednich założeń teoretycznych, w tym antropologicznych, ale również z potrzebą wdrażania systemowych rozwiązań w zakresie regulacji prawnych, finansowych i organizacyjnych. Często bowiem nawet najlepsze działania uwzględniające podmiotowość starszych osób napotykają bariery utrudniające lub uniemożliwiające ich wprowadzenie w życie (jak np. w przypadku personalizacji opieki w instytucjach z ograniczoną liczbą personelu i brakami finansowymi). Potrzeba jest rozwiązań całościowych, integrujących wszystkie podmioty życia społecznego, uwzględniających wielowymiarowość starości - jej potencjał, a zarazem realistyczne możliwości, przyjmujących za kierunek działania tworzenie warunków do godnego starzenia się.

Wartość personalistycznego ujęcia starości tkwi w pozytywnym, realistycznym i pogłębionym spojrzeniu na człowieka w podeszłym wieku. Jest to ujęcie pozytywne, bo ukazuje starość jako „wiek w pełni jeszcze czynny: nie zamknięty i immobilny, lecz otwarty i płodny, [w którym - K.U.-S.] człowiek stary musi wciąż zabiegać o rozwój swojej formacji” (Jan Paweł II 1993), podkreśla jej indywidualny i społeczny potencjał rozwojowy. Realizm przejawia się w uwzględnieniu prawdy o wieku podeszłym, która stanowi warunek konieczny wychowania w perspektywie starości, bowiem „,W sposób właściwy starzeje się jedynie ten, kto starość wewnętrznie aprobuje" (Guardini, cyt. za: Blieweis 1976, s. 66). Jest to również spojrzenie pogłębione, ponieważ nie omija tematów tabu dotyczących starości, niepodejmowanych w sposób wyczerpujący w analizach gerontologicznych. Należą do nich m.in.: wymiar duchowy starości, transcendencja i odkrywanie jej sensu w perspektywie wartości absolutnych; odchodzenie i umieranie jako kluczowe wyzwania egzystencjalne starości; sytuacje osamotnienia i straty; niezgoda na starość własną i innych; a także towarzyszenie osobom starszym w rozwoju (Dubas 2013). 
Egzystencja człowieka starszego ujmowana jest w sposób pełny, bez pomijania zagadnień trudnych, a zarazem szczególnie wymagających.

Co więcej, koncepcja personalistyczna dostarczyć może odpowiedzi na pytania towarzyszące praktyce wychowania w perspektywie starości. Dialog ten przybrać może następującą formę: Czy wychowanie do starości, w starości i przez starość jest zasadne? Tak, bo do końca swoich dni człowiek pozostaje istotą potencjalną, zawsze może się rozwijać lub pomagać, czasem nieświadomie, w rozwoju innym. Czy wychowanie to ma sens? Tak, gdyż osobą stajemy się aż do momentu śmierci, walka o zachowanie godności toczy się przez całe życie, a starość stanowi jej szczególne pole. Jak wychowywać w starości? W poszanowaniu podmiotowości, indywidualności i wolności drugiego człowieka, w dialogu i spotkaniu ze starością, nawet wtedy, gdy przyjmuje ono formę milczącego trwania przy osobie chorej i umierającej. Nie można oczywiście powiedzieć, że personalistyczna koncepcja starości stanowi panaceum na wszystkie problemy z nią związane. Wskazuje jednak kierunek działania (samo)wychowawczego - trudnego, ale możliwego do zrealizowania. Ukazuje jego sens, jakim jest wartość człowieczeństwa samego w sobie, niejednokrotnie przysłonięta przez braki i błędy życiowe, niekorzystne warunki środowiskowe, ciężar wieku i związanych z nim ograniczeń. Paradoksalnie starość, zwłaszcza schorowana i niedołężna, odsłania ukrytą, ale najważniejszą cechę człowieka - osobową godność, wartość niezmienną i „ciągle młodą” (Chudy 2007), stale zobowiązującą do życia na jej miarę. Dlatego też - jak mówił Jan Paweł II - wychowanie, zwłaszcza to dotyczące starości, „winno być skupione nie tylko na tym, co należy «czynić», ale przede wszystkim jak «być»; winno [...] zwracać uwagę na wartości, które każą cenić ludzkie życie na wszystkich etapach, ucząc akceptacji zarówno możliwości, jak i ograniczeń, które ono z sobą niesie" (Jan Paweł II 2002, s. 9).

\section{Bibliografia}

Blieweis T. i in. (red.). Wieczór życia. tłum. Schultz E., Węcławski M. Poznań: Księgarnia Świętego Wojciecha.

Chudy W. (1999). Jesień i zima człowieka. „LOS”, nr 11, s. 33-35.

Chudy W. (1998). Oblicza personalizmu i ich konsekwencje. „Kwartalnik Filozoficzny”, t. 26, z. 6, s. 63-81.

Chudy W. (2007). Odchodzenie z nadzieja. U podstaw pedagogiki umierania. „Ethos”, nr 79-80, s. 21-42.

Czerniawska O. (2000a). Czas i jego wymiary. W: Czerniawska O. Drogi i bezdroża andragogiki i gerontologii. Łódź: Wydawnictwo Wyższej Szkoły Humanistyczno-Ekonomicznej.

Czerniawska O. (20oob). Edukacja osób „trzeciego wieku”. W: Czerniawska O. Drogi i bezdroża andragogiki i gerontologii. Łódź: Wydawnictwo Wyższej Szkoły Humanistyczno-Ekonomicznej. 
Derejczyk J. i in. (2008). Gerontologia i geriatria w Polsce na tle krajów Europy - czy należy inwestować w ich rozwój w naszym kraju? „Gerontologia Polska”, nr 3, s. 149-159.

Dubas E. (2005). Geragogika - dyscyplina pedagogiczna o edukacji w starości i do starości. W: Fabiś A. (red.). Seniorzy w rodzinie, instytucji i społeczeństwie. Wybrane zagadnienia współczesnej gerontologii. Sosnowiec: Wyższa Szkoła Zarządzania i Marketingu w Sosnowcu.

Dubas E. (2013). Starość znana i nieznana - wybrane refleksje nad współczesna starościa. „Rocznik Andragogiczny”, nr 20, s. 135-152.

Gangl J. (1976). Starzenia trzeba się uczyć. W: Blieweis T. i in. (red.). Wieczór życia. tłum. Schultz E., Węcławski M. Poznań: Księgarnia Świętego Wojciecha.

Gołdys A. i in. (2012). Zoom na UTW. Raport z badania, dostępny na: http:// zoomnautw.pl/wp- content/uploads/2012/05/Zoom_na_UTW_RAPORT_calosciowy_www.pdf (otwarty 14.07.2015).

Homplewicz J. (2003). Gerontologia wyzwaniem dla pedagogiki XXI wieku. Wykład inauguracyjny wygłoszony na uroczystości XX-lecia UTW przy UR w Rzeszowie 20 czerwca 2003 roku. W: Księga Pamiątkowa XX-lecia UTW. Rzeszów: Wydawnictwo Uniwersytetu Rzeszowskiego.

Jan Paweł II (2002). Ludzie starsi w życiu społeczeństwa. List papieski do uczestników II Światowego Zgromadzenia poświęconego problemom starzenia się ludności. „L'Osservatore Romano”, nr 6, s. 8-9.

Jan Paweł II (1993). Środki przekazu społecznego a problemy ludzi starych. Tekst opracowany przez Papieska Komisję Środków Przekazu Społecznego. W: Weron E., Jaroch A. (oprac.). Nauczanie papieskie. T. 5, cz. 1. Poznań: Pallottinum.

Kamiński A. (1986). Pedagogika w służbie starości. W: Sawicka F.W., Maryańska B., Stańczuk E. (red.). Encyklopedia seniora. Warszawa: Wiedza Powszechna.

Katz S., Marshall B. (2003). New sex for old: lifestyle, consumerism, and the ethics of aging well. „Journal of Aging Studies”, nr 17 (1), s. 3-16.

King U. (2004). The dance of life. Spirituality, ageing and human flourishing. W: Jewell A. (red.). Ageing, spirituality and well-being. London: Jessica Kingsley Publishers.

Kluczyńska U. (2010). Dziadkowie, ojcowie, synowie a przemiany męskości w kulturze współczesnej. W: Bugajska B. (red.). Młodość i starość. Integracja pokoleń. Szczecin: ZAPOL.

Krąpiec M.A. (1991). Ja - człowiek. Dzieła. T. 9. Lublin: RW KUL.

Krąpiec M.A. (200o). Starzenie się - dojrzewaniem człowieka. „Studia Philosophiae Christianae", nr 2 (36), s. 107-113.

Leclercq J. (1978). Radość zmierzchu, tłum. Burska E. Warszawa: PAX.

Machowicz J. (2003). Osobowość ludzi starszych. W: Homplewicz J. (red.). Pedagogika jesieni. Problemy wychowawcze ludzi starszych. Rzeszów: Poligrafia Wyższego Seminarium Duchownego. 
McIntyre M. (2003). Dignity in dementia: Person-centered care in community. "Journal of Aging Studies”, nr 17 (4), s. 473-484.

Myszka-Wieczerzak M., Sękalska M. (red.). (2009). „Jestem od zamiatania drogi do Kościoła”, z Elżbietą Sujak rozmawia Cezary Sękalski. Kraków: Serafin.

Owsiany E. (2003). Zaproszenie do wieczności. „Pastores”, nr 2, s. 7-15.

Pastuszka J. (1999). Starość człowieka. Rozważania psychologiczne. „Ethos”, nr 47, S. 29-55.

Pawlukiewicz P. (1998). Porozmawiajmy spokojnie o starości. Warszawa: Libertyn. Pietrasiński Z. (1990). Rozwój człowieka dorosłego. Warszawa: Wiedza Powszechna. Racław M. (2011). Opiekunowie nieformalni - „niewidoczne” podmioty. W: Racław M. (red.). Publiczna troska, prywatna opieka. Społeczności lokalne wobec osób starszych. Warszawa: IPS, dostępny na: http://www.archiwum.isp.org.pl/publikacja/wyszukiwarka/1419/znajdz (otwarty 14.07.2015).

Ringel E. (1976). Sztuka akceptowania starości. W: Blieweis T. i in. (red.). Wieczór $\dot{z} y c i a$, tłum. Schultz E., Węcławski M. Poznań: Księgarnia Świętego Wojciecha.

Spaemann R. (2001). Osoby. O różnicy między kimś a czymś, tłum. Merecki J. Warszawa: Oficyna Naukowa.

Starowieyska-Morstinowa Z. (1982). Patrzę i wspominam. Kraków: Znak.

Steuden S. (2011). Psychologia starzenia się i starości. Warszawa: PWN.

Straś-Romanowska M. (2010). Możliwości i ograniczenia rozwoju człowieka starszego związane z przemianami cywilizacyjnymi. W: Kobylarek A., Kozak E. (red.). Starość u progu XXI wieku: Uniwersytety Trzeciego Wieku wobec problemów starzejącego się społeczeństwa. Wrocław: Argi.

Szarota Z. (2004). Gerontologia społeczna i oświatowa. Zarys problematyki. Kraków: Wydawnictwo Naukowe Akademii Pedagogicznej.

Szczepański J. (1988). Sprawy ludzkie. Warszawa: Czytelnik.

Ślipko T. (1999). Sens życia - sens starości w chrześcijaństwie. „Ethos”, nr 47, s. 15-28.

Tarnowski J. (1992). Pedagogika dialogu. W: Śliwerski B. (red.). Edukacja alternatywna. Dylematy teorii i praktyki. Kraków: Oficyna Wydawnicza „Impuls”.

Tomasz z Akwinu (1964). Suma teologiczna. Roztropność, tłum. Bełch S. T. 17. Londyn: Veritas.

Tomczyk Ł. (2010). Seniorzy w świecie nowych mediów. „E-mentor”, nr 4, dostępny na: http://www.e-mentor.edu.pl/artykul/index/numer/36/id/776 (otwarty 14.07.2015).

Uzar K. (2011). Wychowanie w perspektywie starości. Personalistyczne podstawy geragogiki. Lublin: Wydawnictwo KUL.

Wałejko M. (2010). Horyzont osobowego spetnienia - między osamotnieniem a samotnościa osób starszych. Perspektywa antropologiczno-etyczno-pedagogiczna. W: Bugajska B. (red.). Młodość i starość. Integracja pokoleń. Szczecin: ZAPOL. Woroniecki J. (1986). Katolicka etyka wychowawcza. T. 2, cz. 1. Lublin: RW KUL. Zych A. (2007). Leksykon gerontologii. Kraków: Oficyna Wydawnicza „Impuls”. 


\title{
PERSONALISTIC CONCEPT OF AGING AND ITS IMPLICATIONS FOR THE PEDAGOGY OF PERSON
}

\begin{abstract}
Old age is one of contemporary educational challenges. Theoretical and practical aspects of educational gerontology are constantly developed. Personalistic concept of human might provide the adequate foundation for them. Realistic and positive, grounded metaphysically and ethically, view on aging perceived as the time closest to the personal fulfilment, that arises from it, justifies undertaking educational actions concerning this period of life. They might create the scope of education 'to', 'in', and 'through' aging and include persons and societies. Potential project of permanent, integral education related to aging comes across objective obstacles conditioned by the specificity of elderly persons' existence including environments they live in. To live the old age with dignity, what is the aim of personalistic education concerning aging presented in the article, is a particular, possible but demanding, challenge for seniors and aging societies.
\end{abstract}

Key words: old age, personalistic concept of aging, education related to old age and aging, pedagogy of person

Katarzyna Uzar-Szcześniak - doktor pedagogiki, adiunkt w Katedrze Filozofii Wychowania KUL. Autorka monografii Wychowanie w perspektywie starości. Personalistyczne podstawy geragogiki (2011). Adres do korespondencji: Instytut Pedagogiki KUL (p. DMM III - 125), ul. Droga Męczenników Majdanka 70, 20-325 Lublin. Adres e-mail: kuzar@kul.pl. 